\title{
Green-Banking Practices in Bangladesh-A Scope to Make Banking Green
}

Md. Ariful Islam (Corresponding author)

Deputy Manager, BASIC Bank Limited

Khulna Branch, 107 Sir Iqbal Road, Khulna, Bangladesh

Tel: 880-171-752-9503Ｅ-mail: arifrussell@yahoo.com

Kh. Fahim Hossain

Accountant, Chevron Bangladesh Ltd.

57 Gulshan Avenue (4th Floor), Gulshan-1, Dhaka-1212, Bangladesh

Tel: 880-192-666-2131Ｅ-mail: khfahim04@gmail.com

\author{
Mahmudul Hasan Siddiqui \\ Senior Territory Manager, Unilever Bangladesh Limited \\ M.N. Trading \& Co, Modina Tower, Habibpur, Narayanganj, Bangladesh \\ Tel: 880-171-168-8592Ｅ-mail: mhs.sadi@gmail.com
}

\author{
Salahuddin Yousuf \\ School of Management and Business Administration \\ Khulna University, Khulna, Bangladesh \\ Tel: 880-173-451-4040Ｅ-mail: yousufsalahuddinbd@gmail.com \\ Received: February 21, 2014 Accepted: March 19, 2014 Published: March 28, 2014 \\ doi:10.5296/ifb.v1i1.5161 URL: http://dx.doi.org/10.5296/ifb.v1i1.5161
}

\begin{abstract}
In Bangladesh, it is not blamed to pollute environment compare with other countries. Amount
\end{abstract}




\section{Macrothink

of $\mathrm{CO} 2$ emission is also very low comparing with other countries. But we are the victims of this $\mathrm{CO} 2$ emission or environmental pollution. So, to survive ourselves we should incorporate this green banking for the sake of our people. As early as possible the banking community should commence its activities. Government should take necessary steps to enforce existing environmental regulations and formulate appropriate rules to ensure "Pollute Pays Principle" in the country. The Central bank of Bangladesh can play a pro-active role in formulating a national level "Green Credit Policy" and creating a sound incentive structure for performing ER practices by banks. Much more is expected from the civil society organizations in the form of awareness development, research activities and business monitoring. 'Consumer Awareness' is the area where Bangladesh needs remarkable change, because green banking is largely driven by consumer behavior and consumption patterns. For rapid change among consumers and business, a collective endeavor of government, media, NGOs, and banks will be required. An isolated effort by banking communities may not bring much. The success of the proposed framework would depend upon the pro-active role of all stakeholders and a sound incentive structure.

JEL Code: Q56, Q58, G21, M10

Keywords: Green Banking, Financial Institution, CO2, Pollution, Environment, Stakeholder Abbreviations: FI=Financial Institution, BB=Bangladesh Bank, GB=Green Banking 


\section{MInstitute ${ }^{\text {Macrothink }}$}

\section{Introduction}

\subsection{Background of the Study}

Banking system occupies an important place in a nation's economy. A banking institution is indispensable in a modern society. It plays a pivotal role in the economic development of a country and forms the core of the money market in an advanced country. In recent times the banking sector over the world has been undergoing a lot of changes due to deregulation, technological innovation, globalization, environment etc. Bangladesh banking sector is lagging far behind in adopting these changes. But they are trying to adjust their activities with the required necessitate and adopting themselves as world class bank.

As of late another challenge attach with banks to concentrate their finance in the environment frankly industry and avoiding waste and giving priority to society. It is not an easy task. Because banks are also concern about profit. So they have to earn profit in such a way where they could able to give the priority of society also. And the only solution is "GREEN BANKING".

Many developed country already triggered their activities on green banking. And recently Bangladesh is also trying to commence it for the sake of environment and social benefit. At the preliminary stage of commencing this banking system in Bangladesh I have found this opportunity to make my dissertation paper on this subject. My subject is "Green Banking, Bangladesh perspective".

Due to apparently unusual weather patterns, rising greenhouse gases, declining air quality etc. and society demands that businesses also take responsibility in safeguarding the planet, public concern of the state of environment has been growing significantly in the last few years. Banks hold a unique position in an economic system that can affect productions, businesses, and other economic activities through their financing activities. Green bank do not only improve their own standards but also affect socially responsible behavior of other businesses. However, if green banking simply results incurring additional costs by a bank, it might never be accepted as common business practices by the global banking industry. The positive relationship between green banking strategy and profitability has not always been the case. Socially and environmentally responsible banks can also be financially successful and have growth rate similar to, or even better than that of their conventional competitors. In many cases, it is also proven that with a well-managed green banking premium, consumers could be willing to pay extra in the knowledge that the products are environment friendly. Moreover, banks that mainly do businesses with the depositors' money cannot avoid responsibility to the society. It is well known that governments in different countries intervened to save banks using taxpayers' money in response to 2008-09 bank failure during crisis. When the common people have to take care of banks in their bad days, banks must be made responsible to take care of the society as well.

\subsection{Scope of the Study}

Though unknowingly many banks did their green banking activities since long time but it can say that Green Banking activities are in the preliminary stage in our country. So this paper 


\section{Mll Macrothink}

International Finance and Banking

2014, Vol. 1, No. 1

tried to focus on study to initiatives of Green Banking based on global banking industry to draw lesson for Bangladesh Banking Sector.

There is no doubt that complete replication of these practices may not give fruitful output considering the different economic status, consumer groups, business practices, and structure of financial sectors. But still it could play a vital role for our economy.

\subsection{Objective of the Study}

\subsubsection{Broad Objective}

The broad objective of the study is finding out the suitable way to implement Green-Banking practices in Bangladesh. This study aims at a review of green banking initiatives and practices in the global banking industry to draw lessons for Bangladesh Banking Sector. Therefore in this study key objectives will be analysis the possibility, implementation, practices and overall benefit for the society of green banking.

\subsubsection{Specific Objectives}

The specific objectives of this study are as follows:

1) To assess the attempts to initiate green banking in Bangladesh by different stakeholders.

2) To understand current potentials of local banking sector to absorb new way of banking.

3) Cost-benefit analysis of financing a green project by a bank as an example.

4) Carbon Emission, Environmental degradation and responsibility of Bangladesh banking sector.

5) Enforcement of relevant Rules and Regulation for green banking in Bangladesh.

\subsection{Methodology}

It's a qualitative study and the study based on examinations of published information, research papers, sustainability reports of different banks and environmental organization, consultation with bankers and discussions with academicians. Internet will also use as a theoretical sources of information. 


\section{Macrothink}

International Finance and Banking

2014, Vol. 1, No. 1

\begin{tabular}{|c|c|c|c|}
\hline Objectives & Required data & Sources of data & What to do \\
\hline $\begin{array}{l}\text { To assess the attempts to } \\
\text { initiate green banking } \\
\text { practices in Bangladesh by } \\
\text { different stakeholders. }\end{array}$ & $\begin{array}{l}\text { Research paper findings, } \\
\text { Workshop keynote } \\
\text { recommendations, Findings of } \\
\text { project reports }\end{array}$ & 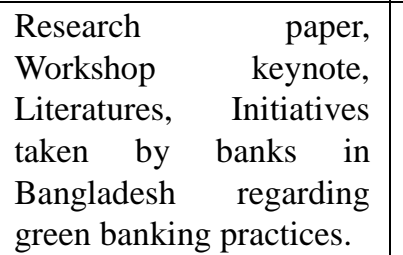 & $\begin{array}{l}\text { To understand the } \\
\text { findings and } \\
\text { analysis part of the } \\
\text { research paper. }\end{array}$ \\
\hline $\begin{array}{l}\text { To understand current } \\
\text { potentials of local banking } \\
\text { sector to absorb new way } \\
\text { of banking. }\end{array}$ & $\begin{array}{l}\text { Existing policy regarding } \\
\text { environment responsibility of } \\
\text { banks in Bangladesh, } \\
\text { Risks associated with the practice, } \\
\text { Potentials for implementing green } \\
\text { banking practices. }\end{array}$ & $\begin{array}{l}\text { Annual reports, Financial } \\
\text { statements, Previous } \\
\text { experience by the } \\
\text { bankers. }\end{array}$ & $\begin{array}{l}\text { To analyze the } \\
\text { possible way to } \\
\text { implement green } \\
\text { banking in } \\
\text { Bangladesh. }\end{array}$ \\
\hline $\begin{array}{l}\text { Cost-benefit analysis of } \\
\text { powering a renewable } \\
\text { energy. (Method: UNIDO } \\
\text { Approach) }\end{array}$ & Hypothetical & Hypothetical & $\begin{array}{l}\text { To analyze the } \\
\text { economic benefit or } \\
\text { losses. }\end{array}$ \\
\hline $\begin{array}{l}\text { Carbon Emission, } \\
\text { Environmental degradation } \\
\text { and responsibility of } \\
\text { Bangladesh banking sector. }\end{array}$ & $\begin{array}{l}\text { Bangladesh Bank publications } \\
\text { Newspaper, } \\
\text { World journal. }\end{array}$ & $\begin{array}{l}\text { Bangladesh } \\
\text { publications } \\
\text { Newspaper, } \\
\text { World journal, }\end{array}$ & $\begin{array}{l}\text { To find out the } \\
\text { responsibility of } \\
\text { Bangladeshi } \\
\text { banking sector to } \\
\text { reduce carbon. }\end{array}$ \\
\hline $\begin{array}{l}\text { Enforcement of relevant } \\
\text { Rules and Regulation for } \\
\text { green banking in } \\
\text { Bangladesh. }\end{array}$ & $\begin{array}{l}\text { Regulatory guidelines to practice } \\
\text { green banking given by central } \\
\text { bank in other countries. }\end{array}$ & $\begin{array}{l}\text { Bangladesh bank website, } \\
\text { Bangladesh bank annual } \\
\text { report. } \\
\text { Other central bank website }\end{array}$ & $\begin{array}{l}\text { To review } \\
\text { regulations } \\
\text { guidelines. }\end{array}$ \\
\hline
\end{tabular}

\section{Initiatives of Green Banking}

\subsection{Definition of Green Banking (GB)}

Green banking can be defined as the financial services to support the activities that are not hazardous to environment and help conserve environment or banks that have given support for carrying out eco-sustainability to their management or of bank institute that invest money for discouraging of Carbon dioxide emission quotas. A green bank is called an ethical bank, a socially responsible bank, or a sustainable bank. The exact meaning of all these titles may not be same however they cover a lot of common activities and perceptions. All these banks-in various ways and at different times-have engaged themselves in making a better future. So the broad objectives of green banks are to use their resources with responsibility avoiding waste and giving priority to environment and society.

Someone may create conflict GB with CSR (Corporate Social Responsibility). There is a little bit up difference between these two terms. In case of CSR Bank are not expecting explicitly from the customer, but in case of GB, banks are directly imposed their earnings (interest).

\subsubsection{Where to Place the Global GB Initiatives?}

GB is a component of global initiatives by a group of stakeholders to save environment. The 


\section{MlMacrothink}

efforts are expected to bring positive changes in the environment, which are mostly non-excludable and non-rival in nature. Thus, as a whole, the ongoing GB initiative by different stakeholders is a GPB (Global Public Bads) where the society as a whole is the target beneficiary.

\subsubsection{Green Banking Financial Products/Services Offered by Banks}

GB products are designed targeting a particular group and are excluded and rival in nature. Generally these are commercial products and have features of private goods. The products that do not harm environment have neither positive nor negative externality. The green products that help to create favorable impact on environment have positive externalities. Carbon emission, saving power especially to encourage the use of alternative energy sources like solar energy, Investment in Brick cleans which using new technology etc.

Generally, a section of the society directly and as a whole the entire society indirectly is the beneficiary of the external benefits offered by banks. Thus banks have the economic rights of charging additional cost of their products.

\subsection{Initiative of Green Banking in Bangladesh}

At the very initial stage it is very important for banks to take right decision about green banking. Bangladesh is a developing country. The product which may be good for developed country may not be good for us. So we have to think about our interest. And by this way we need to design our product. But at the initial moment before initiating green product we need to improve employees' efficiency as well as customer and banks efficiency to handle the green product. So we can divide the initiating stage in four parts-

1) Green initiatives of our employees

2) Green initiatives of our customer

3) Green initiatives of our banks

4) Green initiatives of our regulators

\subsubsection{Green Initiative of Our Employees}

To enhance our employees' efficiency in green activity, we can take the necessary steps:

The first step towards going Green, we should look at our day to day functioning to identify and implement 'Green' measures. These measures ranged from reduction in consumption of energy and paper to employee engagement.

The second step is "Power Go Green Contest". Bank can invite ideas for Going Green from employees through the Power Go Green contest. The contest received an overwhelming response with participation through ideas. The ideas were evaluated and selected for implementation by a panel from the Organization Excellence Group on parameters of effectiveness and efficiency like Novelty, Ease of Implementation, Impact, and Scalability and Cost efficiency. 


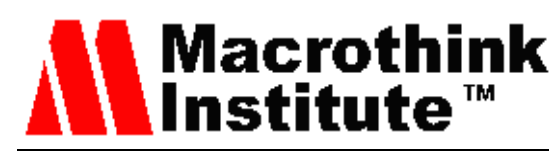

The third step is "Go Green" movement. This movement is based on principles of participation and collaboration and is aimed at moving our people, products and processes to a more environment conscious plane.

The fourth step is "Conserving Energy".

- Encouraging turning off and/or unplugging all lights and electronic equipment (computers, monitors, photocopiers, cell phone chargers, printers, radio, etc.) when not in use, and fully utilizing power-saving settings when in use.

- Recycling and refilling ink cartridges for printers.

- Replacing incandescent bulbs with CFLs when they need to be replaced, internally and externally.

- Encouraging use of carpool and use public transportation.

The fifth step is "Saving Paper"

- Upgrading to a higher percentage post-consumer waste recycled paper internally (copy and printer paper) and externally (brochures, etc.).

- Shredding and recycling all paper internally.

- Sharing electronic files, voice mail and e-mail instead of paper memos.

- Duplexing (two-sided printing) when possible as well as limiting printed materials/e-mails/memos to only what is necessary.

The sixth step is "Dateless Diaries"

It re-affirmed Bank's commitment to going green. With this initiative, you can save trees and enough water to supply to rural households for a month.

The seventh step is "e-calendar"

The e-calendar facilitates paperless operations by allowing the user to set reminders and update appointments. It rests permanently on the desktop and is accessible at the click of a button.

\subsubsection{Green Initiatives of Our Customer}

- Customer must be aware about using green product. Whether banks are maintain green activities or not it should be checked by the customer. So the customer should also take the following initiatives to become a green customer.

- Don't go for any product to banks without green banks.

- Use the borrowed money in the green way.

- Green banking product incorporating the cost of its external benefit. If the cost is added to the price of a loan (with a green feature), borrowers may bear additional cost. Since the overall benefit is economical and long term and we all are benefited from this 
product so here should have a trade-off between customers' bearing extra price and earnings of the bankers.

\subsubsection{Green Initiatives of Our Banks}

Green initiatives aimed at customers are driven by the objective of collaborating with making 'Green' a part of all our lives. These initiatives range from Green offerings/ incentives, Green engagement to Green communication to our customers. The possible steps for a customer to become him green are:-

The first step is "green products and services"

'Instant banking' - It is the platform that brings together all alternate channels under one umbrella and gives customers the convenience of banking anytime anywhere through Internet banking, i-Mobile banking, IVR Banking. This reduces the carbon footprint of the customers by ensuring they do not have to resort to physical statements or travel to their branches.

Vehicle Finance- As an initiative towards more environment friendly way of life, offering Auto loans up to a certain \% waiver on processing fee on car models which uses alternate mode of energy and saving energy and each car that hits the road impacts the environment make an informed choice for a better earth.

Home Finance- By offering Home Finance at reduced processing fees to customers who purchase homes in using Energy and Environmental Design and certified from legal authority.

The second step could be "green involvement" Bank can conducted Green themed events with their customers during special day like Eid, puja etc. occasion to build awareness about the environment amongst employees and customers alike. During this event banks can present to their customers money plant trees or other trees as token of prosperity and also as a token of collective responsibility in building a greener society.

Earth Hour- In furtherance of 'Green' commitment, Bank can pledge its support to the world's largest global climate change event- the 'Earth Hour'. For example on SaturdayMarch 28, 2009, ICICI Bank switched off all lights in its premises, Branches and ATMs between 8.30 PM- 9.30 PM- the designated 'Earth Hour'. It is sure; one hour of darkness will help bring to light one of our generation's largest challenges "Climate Change".

World Environment Day- June 5, 2009- Every Bank should celebrate the World Environment Day on June 5, 2009. To mark the occasion, branches across the country should undertake a number of activities. Branches along with their customers can take the green pledge through signature campaigns, planted and distributed saplings, conducted drawing and painting competition for children, conducted cycle rallies.

The third step is "Green Communication" Bank should extensively capitalized on the existing internal media- statements, inserts, Credit Card Charge slips- to reach out to the customers and seek their collaboration in the 'Go Green' movement. The communication on Online Bill pay, Online Funds Transfer and Subscribing to e-statements are aimed at 


\section{Macrothink $\triangle$ Institute ${ }^{\text {tw }}$}

migrating customers to 'paperless' and 'commute-free' mode of conducting some of their banking transactions.

The fourth step is "Green Partners" Banks can work on and looking forward to partnerships with national and international 'Green' organizations and NGOs.

\subsubsection{Green Initiatives of Our Regulators}

In the Endeavour of emission reduction and conservation, Regulators will have to contribute in many ways. International financial institutions and Inter Governmental Organizations have to be engaged in designing principles and undertaking environmental and awareness development programs; government and central banks have to be enacting relevant rules and regulations and enforce emission trading.

Role of Stakeholders in the Development of Green Banking

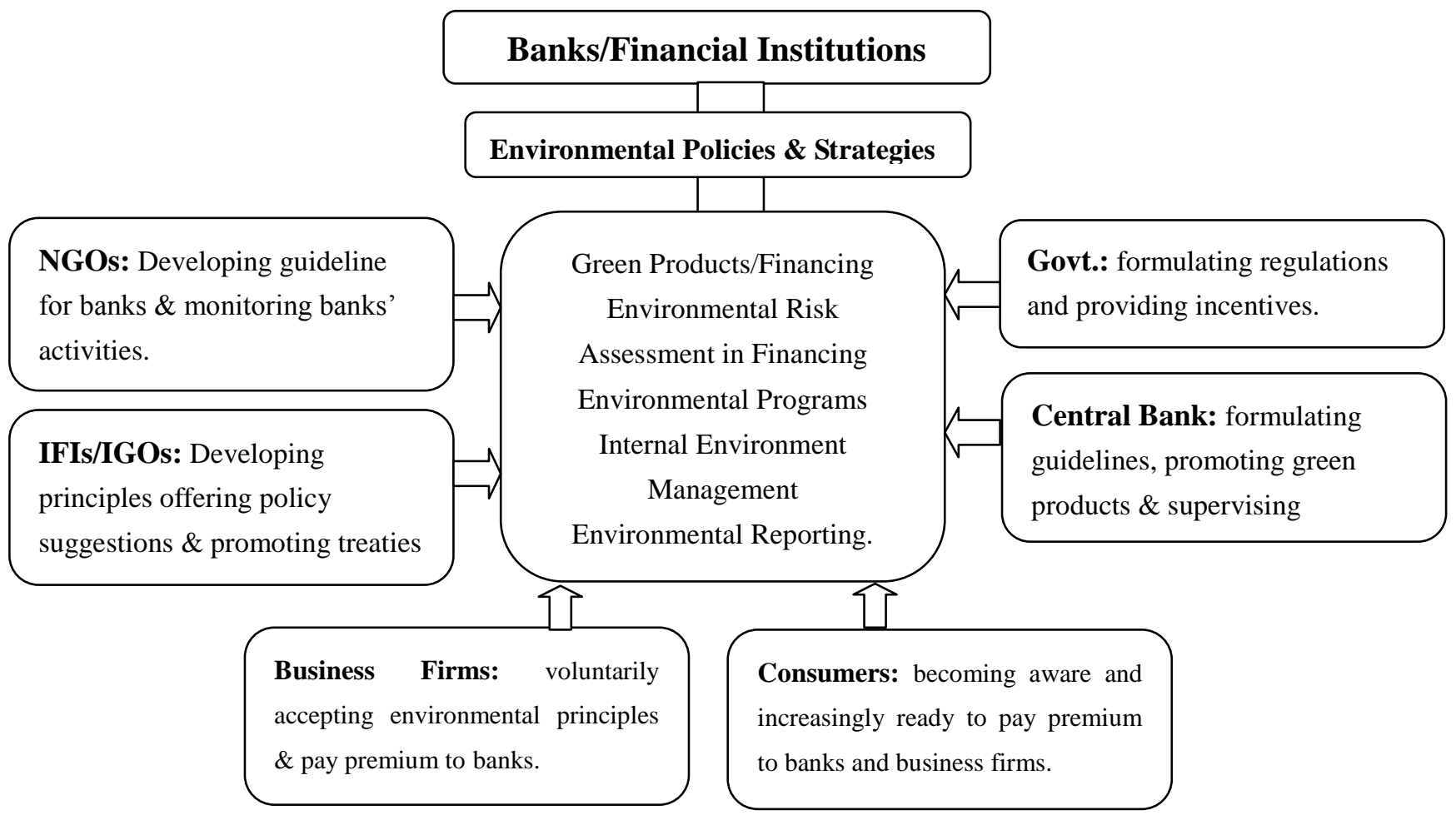

Figure 1. Role of stakeholders in the development of green banking

Sources: seminar paper on "Green Banking Initiatives: Opportunities for Bangladesh"

\section{Fundamental Discussion of Green Banking}

The creation of a Green Bank will encourage a long overdue integrated and strategic approach to clean-energy innovation, efficiency, and deployment. In combination with Senate action on clean energy-legislation that provides incentives for the research, development, and deployment of clean-energy technologies, and a market-based pollution-reduction program that reduces greenhouse gas emissions and reinforces a predictable price signal on carbon - the Green Bank will open credit markets, motivate private business to invest again, 


\section{Macrothink}

and create good, clean-energy jobs.

In partnership with the private sector, the Green Bank will enable innovative, commercially viable clean-energy technologies in such areas as wind, solar, geothermal, advanced biomass, increased efficiency, and transmission infrastructure - all to be deployed on a large scale. No single technology must be allowed to absorb a disproportionate share of the funding. A Green Bank will operate in an open and transparent manner, and will be held publicly accountable for its lending activities. The construction and actual deployment of existing commercial and breakthrough clean-energy technology projects is vital to a clean-energy future.

What's more, clean energy delivers long-term job growth and holds tremendous new job-creation potential, particularly in the manufacturing sector. A recent report from the Center for American Progress and the University of Massachusetts Political Economy Research Institute notes that $\$ 150$ billion per year in clean-energy investment can generate a net increase of 1.7 million jobs.

In short, the Green Bank can encourage the rapid deployment of clean energy and ensure that lower energy costs are passed on to consumers. In addition, the Green Bank can act as a bulwark against higher energy costs associated with volatile fossil fuel prices.

\subsection{Costs and Benefits of the Green Bank}

A Green Bank funded at $\$ 7.5$ billion could fund generation of 60 to 80 gigawatts of clean energy over a period of 20 years, or 3 to $4 \mathrm{GW}$ annually. The result: National security will be enhanced by reducing our dependence on foreign oil. A fully capitalized Green Bank at $\$ 50$ billion could:

- Provide enough electricity to power approximately 22.9 million cars per year.

- Decrease gasoline consumption by an incremental 12.6 billion gallons per year.

- Decrease oil consumption by an incremental 642 million barrels per year, or 1.8 million barrels per day.

\subsubsection{Direct Support}

Equity investments are important, but the deployment of major clean-energy projects will also require significant loans and low-cost debt financing. The Green Bank will marshal a variety of well-established financial tools and incentives to enable the government to enlist the private sector to increase the amount of debt capital available at lower rates to clean-energy projects. A Green Bank can vastly expand the tools available to lenders by providing direct support, such as direct loans, letters of credit, and loan guarantees, and indirect support, such as authority to issue bonds, purchase debt securities, and other financial products.

\subsubsection{Reduce cost of Debts}

In a clean-energy project, the Green Bank can potentially reduce the cost of debt by half- to about 4.5 percent in today's credit markets from around 8.5 percent without govt. support. As 
the cost of debt is reduced, projects can still provide a 15 percent return on equity and meet debt coverage ratios without an increase in electricity rates. The upshot: By lowering the cost of debt, the Green Bank allows utilities to provide the same levels of electricity from clean-energy sources without passing on any additional costs to the consumer.

The result will jumpstart business investment, increase capital at reduced loan rates, lower energy prices to consumers, and spur the construction and operation of more clean-energy technology and energy efficiency projects throughout the country.

\subsubsection{Jumpstarting Private Sector Investments in Clean Energy}

A Green Bank is essential because many clean-energy technologies face several unique obstacles along the path to large-scale deployment and then to the delivery of clean energy in our homes. Traditional banks and commercial lenders are reluctant to loan to many of these clean-energy projects with limited track records in the marketplace.

And many existing off-the-shelf clean energy and efficiency technologies are abandoned due to a lack of funding as they attempt to be deployed at larger scale.

Indeed, renewable energy investment dropped precipitously in the first quarter of 2009, the period for which complete data are available, to $\$ 500$ million compared to $\$ 2$ billion in the fourth quarter of 2008 and $\$ 5$ billion in the first quarter of 2008.

In order to maximize the leverage of private capital, the Green Bank should have at its disposal a wide range of direct and indirect support tools and incentives to encourage loans to facilitate deployment of clean-energy technology. These direct and indirect incentives tend to reduce the risk to lenders so they are encouraged, in turn, to offer better loan rates to potential clean energy and energy efficiency projects.

A Green Bank capitalized with $\$ 10$ billion can leverage capital at the standard 10-1 ratio to provide loan guarantees in support of $\$ 100$ billion in private-sector investment in clean energy. The private sector can also provide an additional $\$ 100$ billion in equity. As a result, a $\$ 10$ billion capitalization of the Green Bank translates into $\$ 200$ billion available for in clean-energy investments.

The surge in capital will allow clean-energy projects to be deployed at the operational and commercial level in a shorter timeframe than is standard today. As clean-energy and efficiency technology is deployed at a larger scale, valuable experience and cost savings will be gained, and more and more clean energy will be delivered to homes at lower prices in every region of the country. The United States will reclaim its rightful place as a global leader in clean-energy technology.

\subsubsection{The Green Bank Creates Clean-Energy Jobs}

As a nation, we can and must do better at nurturing and growing our clean-energy sector and clean-energy jobs, because competitors in other countries are already filling the void. A Green Bank will ensure the United States is a job leader in the clean-energy technology growth industry of the future. 


\section{MInstitute Mach $^{m}$}

Clean energy has the potential to create significant jobs in the manufacturing sector. A Green Bank will provide low-cost capital to help build clean-energy manufacturing facilities, create long-term jobs in the United States, and deliver clean energy at lower cost to consumers. As noted above, a recent Center for American Progress-University of Massachusetts Political Economy Research Institute report demonstrates that $\$ 150$ billion per year in clean-energy investment can generate a net increase of 1.7 million jobs.

A significant portion of these jobs will occur in the struggling construction and manufacturing sectors. Moreover, the CAP-PERI report also notes that clean-energy investments generate roughly three times more jobs than an equivalent amount of money spent on jobs related to carbon-based fuels.

\subsubsection{Ensure Several Energy Manufacturing Sector}

A Green Bank can ensure the clean-energy manufacturing sector is able to overcome several challenges, including securing access to capital when prospective lenders are reluctant to provide financing to manufacturers producing clean-energy technology. Frequently, clean-energy businesses are small, innovative, and highly specialized. They often have limited collateral and revenue and face cost uncertainties, as supply and demand for finished product fluctuates. The Green Bank can provide stability and incentives to leverage private capital, raise the comfort level of prospective lenders, and allow manufacturers to meet their goals and set us firmly on the path to long-term job growth and a clean-energy economy.

\subsubsection{The Green Bank Can Lower Carbon Emissions to Reduce Global Warming}

The establishment of a Green Bank will provide a coordinated, strategic approach to clean-energy innovation and energy efficiency in the United States, enhance federal government and private sector complementary efforts to reduce carbon emissions, and deliver clean energy to American homes in as short a timeframe as possible.

A Green Bank, governed by a board of directors and comprising additional members with clean-energy and energy efficiency financial expertise, will make a significant contribution to the nation's overall energy innovation strategy and project funding decisions. Importantly, the Green Bank will not place the federal government in the role of picking winners and losers in specific clean technologies. Rather, the Green Bank would establish broad, overarching performance-based goals such as the deployment of clean energy that diversifies our energy supply, and reduces or sequesters greenhouse gases.

The Green Bank will work in an integrated manner with clean-energy and climate change legislation that promotes clean energy, energy efficiency, limits on global warming, clean-energy jobs, and transition investment to ensure U.S. competitiveness. The Green Bank has the potential to reduce carbon emissions by an estimated 22 to 59 million metric tons a year, which would be the equivalent of:

- Taking between 4 million and 10 million cars off the road every year

- Neutralizing the carbon emissions of between 15 and 39 power plants every year 


\section{Macrothink}

\subsubsection{Meet the Demand Created by National Renewable Electricity}

The Green Bank also can help meet the demand created by a national renewable electricity standard, and it will encourage the deployment of a smart grid and modernized transmission to ensure supply comes from optimal locations throughout the country. In addition, energy efficiency projects financed by the Green Bank would include any project that results in a net reduction in energy use required to achieve the same level of service prior to their application. Such projects would include smart-grid technologies and energy efficiency gains in existing buildings and new construction.

Smaller projects could be aggregated so as to attract more financing in an area where it has been difficult to secure financing in the past. As noted above, credit support from the Green Bank includes a wide-ranging toolbox (including direct loans, letters of credit, and loan guarantees) that will assist states, localities, and the private sector in rolling out innovative mechanisms to finance building energy efficiency retrofits at scale. This includes municipal bonds, utility loans with on-bill repayment, and increasing commercial loans for retrofits, as the Green Bank effectively lowers the uncertainty and technological risk associated with a lack of historic performance data.

All of these goals would be interwoven into expedited funding decisions as projects were evaluated for viability and creditworthiness by a professional and experienced staff. In sum, the Green Bank will provide the means to allow us to meet our most ambitious carbon reduction targets while promoting clean-energy jobs to ensure U.S. industry and workers will be leaders in the clean-energy technology future.

\subsubsection{Green Finance Can Create a Cleaner and Greener Future}

Green banking has a direct, positive effect on the environment, but the benefits go much further, reaching into security and cost. Green finance may cover all financial services related to the promotion and development of green industry and green economy. Banks are believed to have in unique position to bring positive impact on global climate change and biological diversity in the earth. By incorporating sustainability issues into their lending decisions, banks can both develop profitable lines of business and help build a cleaner, greener future.

\section{Green Banking Practices by Banks in Bangladesh}

Green banking in Bangladesh is at implementing stage. Few banks are doing this banking without knowing the term. But this is not in full fledge. For example, The Prime Bank Ltd., The Mutual Trust Bank Ltd., The Islami Commercial Bank Ltd., The Dutch Bangla Bank Ltd., The Brac Bank Ltd. etc. Few other banks are also member of this club. Bangladesh Bank is also trying to prepare the green banking guideline for this banking system. In this paper few banks are taken as a sample of analysis to attend the present status of green banking in Bangladesh.

Banks are always committed in discharging its due social commitment and its especially concerned about the impact of Bank's financed projects on surrounding environment. Since there is no green banking guideline yet in Bangladesh, banks are following the Environmental 


\section{Macrothink}

Policy formulated in accordance with guidelines issued by the government. As per policy environmental impact will be considered at the time of credit and lending risks analysis. With a view to reduce to reduction and pledge for a green banking Bangladesh, banks are expending following support:

- Financed many CNG conversion projects which are environment friendly and directly reducing the environment pollution of the country. For example, Prime Bank Ltd. financed Tk 350 million to establish 13 new CNG refueling stations as well as provided Tk 80 million to 15 such existing projects.

- Supported establishment and operation of handful of Effluent Treatment Plant (ETP) for dying and other RMG industries. For example recently DBBL has financed Tk 20 crore in an RMG industry to set up their ETP plant.

- Convert vehicles of Bank transportation pool and those of employees to run on CNG.

- Banks are participating in building roads and bridges, development and maintenance of numerous roads and bridges. For example, Prime Bank Ltd. financed second Sitalakhhya Bridge, Teesta Bridge, Dapdapia Bridge, reconstraction of Chittagong-Dohazari National Highway etc.

- Banks are participating in big project by syndication finance. For example, Prime Bank Ltd. financed Tk 500 million for supporting established of five power projects with total capacity of $150 \mathrm{MW}$. Besides, extended working capital support of Tk 610 million to a $110 \mathrm{MW}$ barge mounted power project.

- They are also financing long term finance in Telecommunication sector. Prime bank finance Tk 700 million to the largest mobile operator of Bangladesh. Besides the bank is also arrenged 528 million for establishment of an interconnection exchange project in the country.

- Banks are contributing to finance in Information Technology also. Prime bank financed establishment of the only private sector international gateway operator of Bangladesh.

- Many banks are already prepare a guideline to finance eco-friendly projects. For example, DBBL introduced a guideline demanding assessment of environmental to ensure that operations of the projects would be eco-friendly.

- Some banks have converted their selected staff training sessions into e-learning process. Brac Bank Ltd. is the example of these activities.

- Banks are trying to encourage their customers to sign up for e-statement, Internet banking \& SMS banking facilities.

- Most of the banks are now trying to reduce the wastage of Paper. For example Brac Bank printout and photocopies double-side where necessary and paper communications between the divisions/customer centers have been replaced with on-line communication where possible, resulting in significant reduction in paper usage. 


\section{Al Macrothink}

Though banks are running their activities without concerning environmental issue in Bangladesh but this is the time to change our observation and turn into green banking activities. Banks in Bangladesh are at the implementation stage of green banking and they are trying to accommodate themselves as a green banker.

\section{Powering Renewable Energy: Cost Benefit Analysis for a Renewable Energy Strategy: International Experience}

The main reason for doing SCBA in project is to subject a project to a consistent set of general objectives and national policy. The choice of reviewing different project is not only in term of the profitability but also it must be view in the context of national impact and this total impact has to be evaluated in terms of consistent and appropriate set of objectives. In this report cost benefit analysis of the renewable energy strategy looks in detail at the non-technical parameters concerned with the various options. These cover:

- Economic issues- including market costs and prices

- Environmental issues- both in terms of national effects such as global warming and atmospheric pollution, but also local environmental effects such as noise, and visual intrusion.

- Social issues- concerning level of employment, regional development and overall attitude of the population towards the technologies and specific options proposed.

Table 1. Summary of potential contribution of different renewable energy options for meeting electricity and total energy demand

\begin{tabular}{|l|c|c|c|c|c|c|c|c|c|c|}
\hline $\begin{array}{l}\text { Type of Renewable } \\
\text { of Energy }\end{array}$ & $\begin{array}{l}\text { Practicable } \\
\text { Resource } \\
(\mathrm{MW})\end{array}$ & $\begin{array}{l}\text { Practicable Annual } \\
\text { Energy Output } \\
\text { Electricity (GWh) }\end{array}$ & \multicolumn{2}{l|}{$\begin{array}{l}\text { Practicable } \\
\text { Annual Energy } \\
\text { Output Heat } \\
(\mathrm{GWh})\end{array}$} & $\begin{array}{l}\text { \% Achievable } \\
\text { Contribution to } \\
\text { 2011 Electricity } \\
\text { Demand }\end{array}$ & $\begin{array}{l}\text { \% Achievable } \\
\text { Contribution to } \\
\text { 2011 Total } \\
\text { Energy Demand }\end{array}$ \\
\hline & $\mathrm{LB}$ & $\mathrm{UB}$ & $\mathrm{LB}$ & $\mathrm{UB}$ & $\mathrm{LB}$ & $\mathrm{UB}$ & $\mathrm{LB}$ & $\mathrm{UB}$ & $\mathrm{LB}$ & $\mathrm{UB}$ \\
\hline Wind on shore & 12.0 & 18.0 & 30.0 & 44.9 & $\mathrm{n} / \mathrm{a}$ & $\mathrm{n} / \mathrm{a}$ & $5.1 \%$ & $7.7 \%$ & $0.9 \%$ & $1.3 \%$ \\
\hline Wind off shore & 0.00 & 50.0 & 0.00 & 159.9 & $\mathrm{n} / \mathrm{a}$ & $\mathrm{n} / \mathrm{a}$ & $0.0 \%$ & $27.2 \%$ & $0.0 \%$ & $4.6 \%$ \\
\hline Solar water heating & $\mathrm{n} / \mathrm{a}$ & $\mathrm{n} / \mathrm{a}$ & $\mathrm{n} / \mathrm{a}$ & $\mathrm{n} / \mathrm{a}$ & 0.2 & 0.5 & $\mathrm{n} / \mathrm{a}$ & $\mathrm{n} / \mathrm{a}$ & $0.01 \%$ & $0.01 \%$ \\
\hline Solar photovoltaic & 0.00 & 0.1 & 0.0 & 0.1 & $\mathrm{n} / \mathrm{a}$ & $\mathrm{n} / \mathrm{a}$ & $0.00 \%$ & $0.02 \%$ & $0.00 \%$ & $0.00 \%$ \\
\hline
\end{tabular}

$\mathrm{LB}=$ Lower bound

$\mathrm{UB}=$ Upper bound

Sources: European Commission, Energy for the future: Renewable Sources of Energy

This study uses the figures above in the development of the cost benefit analysis for the strategy and considers the non-technical issues for each strategy within both the upper and lower bounds. The table below is a summary of the local environmental and social impact indicators that are of particular relevance to the specific technology and a summary of the specific economic costs. 


\section{Macrothink}

Table 2. List of social and environmental impact indicators and their economic cost

\begin{tabular}{|c|c|c|c|}
\hline Renewable Technology & $\begin{array}{l}\text { Specific Environmental } \\
\text { Impact Indicators }\end{array}$ & $\begin{array}{l}\text { Specific Social Impact } \\
\text { Indicators }\end{array}$ & $\begin{array}{l}\text { Specific Economic Cost } \\
\text { (with assumption) }\end{array}$ \\
\hline Wind on shore & $\begin{array}{l}\text { Noise } \\
\text { Visual } \\
\text { Impact on landscape } \\
\text { Effect on birds } \\
\text { Planning process } \\
\text { Use of land }\end{array}$ & $\begin{array}{l}\text { Community cohesion } \\
\text { Tourism } \\
\text { Political } \\
\text { Employment } \\
\text { Education } \\
\text { Self-reliance }\end{array}$ & $\begin{array}{l}\text { Economic: } 2.9-3.6 \\
\text { p/KWH }\end{array}$ \\
\hline Wind off shore & $\begin{array}{l}\text { Noise } \\
\text { Visual } \\
\text { Impact on landscape } \\
\text { Effect on birds } \\
\text { Planning process } \\
\text { Recreational }\end{array}$ & $\begin{array}{l}\text { Tourism } \\
\text { Political } \\
\text { Employment }\end{array}$ & Economic: 3.6 p/KWH \\
\hline Solar water heating & Visual & $\begin{array}{l}\text { Employment } \\
\text { Education, Self-reliance }\end{array}$ & $\begin{array}{l}\text { Economic: } 13.9-20.9 \\
\text { p/kWh }\end{array}$ \\
\hline Solar photovoltaic & Visual & $\begin{array}{l}\text { Employment, Education } \\
\text { Self-reliance }\end{array}$ & $\begin{array}{l}\text { Economic: } 78.5-104.7 \\
\text { p/kWh }\end{array}$ \\
\hline
\end{tabular}

Sources: European Commission, Energy for the future: Renewable Sources of Energy

In terms of the economic analysis the costs and prices were taken from data collected during the background analysis and from other available information. The costs included capital, fuel and Operation and Maintenance (O\&M) costs. The capital costs were annuitized - using specific lifetime figures and discount rates. The annual costs of fuel and O\&M were added to this capital cost to give a total energy cost. The direct economic cost in $\mathrm{p} / \mathrm{kWh}$ is then calculated based on the energy output of the system. A simple rate of return (average annual return divided by capital cost) - ROR- has also been calculated to provide a pseudo measure of profitability, ignoring discounting.

The economic figures can, by their very nature, be quantified, whereas the social and environmental indicators are generally hidden impacts and may be viewed either as external costs (i.e. to the environment - local and/or global) or as external benefits (i.e. job creation). The social and environmental indicators have been quantified using data from an EU project that researched these costs in detail for a wide range of electricity producing technologies. A range has been given for these costs and an average taken in order to calculate the final production cost including all of these externalities.

A list of the social and environmental impact indicators is included in the report- as although a quantitative figure has been given overall, many of these are qualitative and need to be considered further in a Strategy. A simple ROR for the production cost was calculatedincluding the economic cost and the average social and environmental cost. The increase in the ROR when social and environmental costs are included was then calculated.

The following two graphs show the economic costs and the total production costs (i.e. 
including the social and environmental costs) - section 8 of the report gives these in more detail. Please note solar PV is not shown as its costs are very high and distorted the graphs.

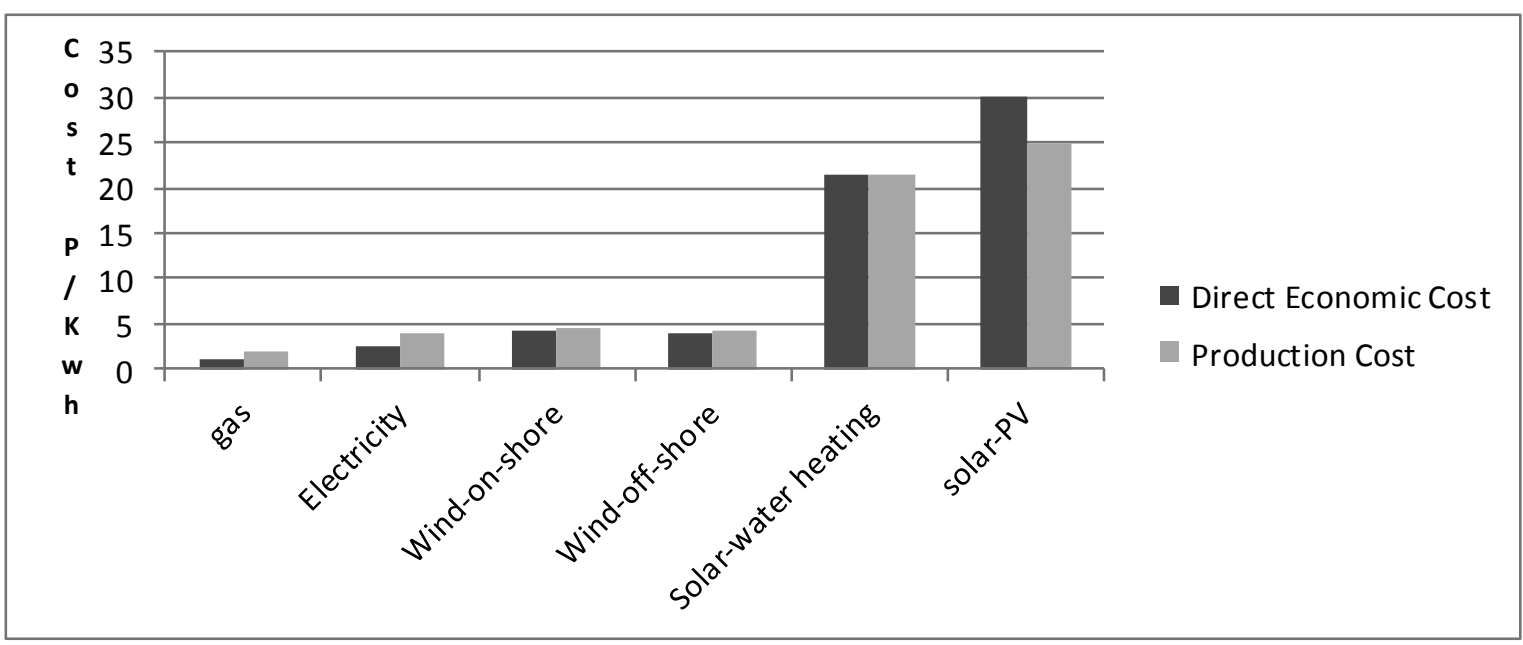

Figure 2. Lower bound economic cost for specific cost

Sources: European Commission, Energy for the future: Renewable Sources of Energy

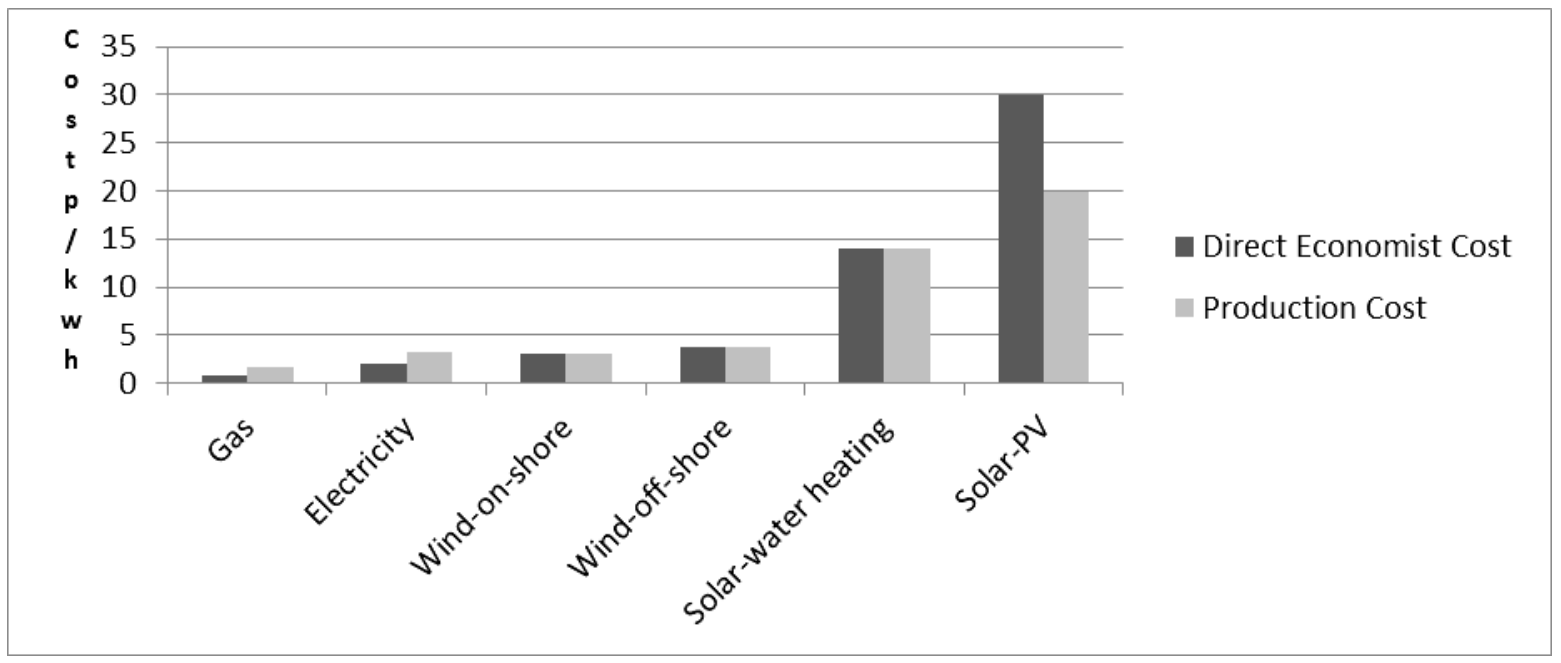

Figure 3. Upper bound economic cost for specific cost

Sources: European Commission, Energy for the future: Renewable Sources of Energy

\subsection{Renewable Energy}

\subsubsection{Wind On-Shore}

The on-shore wind option considered three alternatives - the lower bound considered 5 clusters of 4 small machines $(600 \mathrm{~kW})$ and one larger farm with 8 machines $(1.5 \mathrm{MW})$. The lower overall capital cost of the second option makes it cheaper per $\mathrm{kWh}$, but the social and environmental impacts would needed to be carefully considered. The upper bound considers a cluster of six machines in two wind farms. 


\section{Ml Macrothink}

\subsubsection{Wind Off-Shore}

The off-shore wind option is only included in the upper bound and would consist of 25 machines of $2 \mathrm{MW}$. It is expected that the capital cost of these installations will fall as the industry develops, hence reducing the final electricity cost.

\subsubsection{Solar Water Heat}

The solar water heaters for the lower bound were calculated on the assumption that they were only being used for domestic water heating on single retrofit properties. The upper bound was based on the assumption that they would also be used for new buildings and with bulk purchase. Additional savings and hence an overall lower price for the energy output would be achieved if a significant number of systems were used to heat swimming pools.

\subsubsection{Solar Photovoltaic}

The Solar PV targets were based on small domestic installations of $1.5 \mathrm{kWp}$. The high capital cost for the relatively low amounts of electrical power make the economic cost very high. However these systems have very low social and environmental costs.

\subsection{Impact Indicators}

The approach taken towards producing a Cost-Benefit Analysis has been to construct a list of the economic, environmental and social indicators. The economic figures can, by their very nature, be quantified, whereas the social and environmental indicators are generally hidden impacts and may be viewed either as external costs (i.e. to the environment - local and/or global) or as external benefits (i.e. job creation).

The table below summarizes the impact indicators for all energy technologies- both the Renewable Energy Technologies and the conventional technologies that they are replacing.

Table 3. Summary of all impact indicators for all the technologies considered

\begin{tabular}{|l|l|l|}
\hline \multicolumn{2}{|c|}{ Economic } & \multicolumn{1}{c|}{ Environmental } \\
\hline Resource extraction & $\begin{array}{l}\text { Emission } \\
\text {-Climate change } \\
\text {-Acid rain }\end{array}$ & Education \\
\hline Resource transportation & Noise & Employment \\
\hline Material processing & Visual & Health \\
\hline Establishment of crop & $\begin{array}{l}\text { Effect on wildlife/biodiversity/soil } \\
\text { structure and/or erosion, local } \\
\text { hydrology. }\end{array}$ & Political \\
\hline Cultivation of crop & Landscape & Tourism \\
\hline Harvesting & Planning-issue & $\begin{array}{l}\text { Energy diversification } \\
\text { and security of supply }\end{array}$ \\
\hline $\begin{array}{l}\text { Collection (of crop or } \\
\text { waste) }\end{array}$ & $\begin{array}{l}\text { Planning process cost- including } \\
\text { Environment Impact Assessment }\end{array}$ & \\
\hline Transportation (of crop or & Recreation & \\
\hline
\end{tabular}




\begin{tabular}{|l|l|l|}
\hline waste) & & \\
\hline $\begin{array}{l}\text { Processing (of crop or } \\
\text { waste) }\end{array}$ & Risk abatement & \\
\hline Component manufacture & Loss of agriculture land & \\
\hline Component transportation & Energy pay-back & \\
\hline Plant construction & $\begin{array}{l}\text { Transport of primary fuel, equipment, } \\
\text { crops etc- local and global issues. }\end{array}$ & \\
\hline Plant O\&M & De-commissioning & \\
\hline Duty & Product/by product disposal & \\
\hline Potential sources of funding & & \\
\hline
\end{tabular}

\subsubsection{Economic Impact Indicators}

The Economic analysis uses the commonly recognized market indicators which include the following:

\subsubsection{Capital Costs}

This is the main expense for renewable energy projects. It includes the costs associated with actually purchasing and installing the project hardware.

\subsubsection{Project Development Costs}

These can be very significant and may include (depending on the project type/technology involved):

- Technical, legal and planning consultants' fees, and the farmer or developer's own time, in negotiations with legal and statutory bodies (for example in obtaining planning permission and consulting the Environment Agency)

- Financing and legal costs, including the costs of arranging finance

- Electrical connection costs

- Costs of licenses (for example, if imported food processing residues are used, a Waste Management License will be required, which will involve an initial charge and an annual fee)

\subsubsection{Running and Operation and Maintenance Costs}

The running costs vary enormously for different technologies and projects depending on variations in design and operating circumstances. Running costs will include:

- Fuel costs, if applicable, it can include direct costs, or collection, (i.e. of biomass).

- $\quad$ Staff costs

- Insurance

- $\quad$ Transport costs

- Annual fees for licenses and pollution control measures 


\section{Macrothink}

- General maintenance and operating costs, of plant, equipment, site, etc.

\subsubsection{Training Costs}

Training is an often forgotten or ignored part of the overall project cost. The people who run energy projects/plants, of whatever size and technology, need to be fully trained in the safety, financial and environmental implications of the project. These skills will need to be updated as technology and knowledge develops.

\subsubsection{Income}

The key income will be from the sale of energy (including avoided cost and sales), often in the form of electrical energy. However it should be remembered that by-products can contribute to the overall income, i.e. for anaerobic digestion the fibre sales can produce a significant income. Markets for all the products will need to be developed and balanced for the project to be economically viable. The way the project develops depends on the priority product for the developer (that is for biomass anaerobic digestion systems, energy, fibre or liquor), which will have implications for the technology which should be chosen.

In summary, income streams are likely to include:

- Electricity sales (or displaced purchases); energy from renewable sources is likely to continue to command premium rates

- Heat sales (or displaced purchases)

- $\quad$ By product sales (or displaced costs)

- Savings i.e. for anaerobic digestion on slurry handling and other waste management costs.

\subsubsection{Financing the Project}

Most renewable energy systems will require a large amount of capital investment and, in most cases, developers will require finance from an external source.

There are two types of loan: those secured against the developer's existing assets (on balance sheet financing), and those secured against future cash flows (limited recourse project financing). It is unlikely that a lender will finance $100 \%$ of a project's costs. Between $20 \%$ $40 \%$ may have to be funded by the developer.

Traditional investors do not recognize the environmental benefits and sustainability of renewable energies and view it in the same way as any other high-risk commercial project, demanding high security and high returns on invested capital, leaving less for other investors and shareholders. Ethical or 'green' banks and funds are beginning to appear. They take a more sympathetic view of renewable energy in general and seem willing to invest on less onerous terms. These could be sought by renewable energy project developers, particularly those whose projects fall into the financing gap described earlier. Certain Regional Electricity Companies (RECs) may be interested in supporting (through investment) alternative 


\section{Macrothink}

renewable energy sources in some areas.

\subsubsection{Social Impact Indicators}

It is important to consider that the social aspects of any project especially in gaining local support and acceptance of a particular project. Social assessments are used to evaluate the local (or regional or national) implications of implementing particular strategy. Some of these can be quantified in terms of local employment gains and income increases. However many of them are particular to an individuals or communities perception and are difficult to quantify.

\subsubsection{Employment}

Green Paper on renewable energies the development of renewable can bring positive and tangible effects on regional development and employment. It can bring employment to regions which are otherwise deprived of industrial development, as well as a supply of energy resources necessary for development.

\subsubsection{Education}

Having systems "to hand" provides young people to learn about renewable energy sources and introduce sustainable development, first hand.

\subsubsection{Tourism}

There have been numerous cases of renewable energy developments being used to simulate "green" tourism.

\subsubsection{Self-Reliance}

This applies not only to individual systems rather than those that supply directly to the grid on a specific small plant and local level. It refers to the benefit of not relying solely on the grid but having the option and security of other sources of energy. This is equally true on an extended level for the whole island.

\subsubsection{Community Benefits}

These are interrelated with the benefits of self-reliance but also, for specific projects, include involvement of the community in areas such as:

- Financial return - this can be for the individual but also for the community for community based schemes

- Diversification of rural incomes

- An increase in local employment as discussed above

- A contribution towards environmental sustainability - minimizing Ecological Footprint, and potential for combining with Green Tourism.

- Some degree of control over the scheme for the community, for community based schemes. 


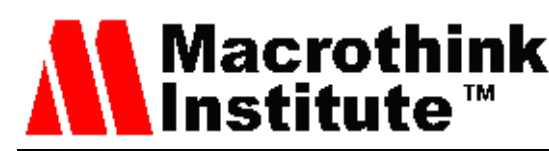

- A sense of satisfaction for those involved and building capacity and strength of community.

\subsubsection{Health}

Health hazards relate not only to the operation of the plant and associated equipment but also to all interrelated factors - such as air quality due to crop choice, i.e. oil seed rape for biodiesel production.

\subsubsection{Political}

There may be costs/savings associated with objections/support from local groups, i.e. planning processes may need to be extended and include public consultation.

Table 4. Summary of social impacts

\begin{tabular}{|c|c|c|c|c|}
\hline Impact Indicator & Receptor & Effect & $\begin{array}{l}\text { Suggested } \\
\text { Prioritization }\end{array}$ & Impact level \\
\hline Employment & Public & Increased employment & & \\
\hline Education & Local & & & \\
\hline Tourism & Local People & Income/Publicity & & \\
\hline Community benefits & Local People & $\begin{array}{l}\text { Local cohesion / } \\
\text { ownership benefits }\end{array}$ & & $\begin{array}{l}\text { Low, Medium } \\
\text { and High }\end{array}$ \\
\hline $\begin{array}{l}\text { Self-reliance- } \\
\text { Individual system }\end{array}$ & $\begin{array}{l}\text { Local groups / } \\
\text { Industry }\end{array}$ & & & \\
\hline $\begin{array}{l}\text { Self-reliance-Energy } \\
\text { diversification and } \\
\text { security of supply }\end{array}$ & $\begin{array}{l}\text { Whole } \\
\text { country }\end{array}$ & Added security & & \\
\hline Health & Industry works & Accidents & & \\
\hline Political & & & & \\
\hline
\end{tabular}

\subsubsection{Environmental Impact Indicators}

The environmental analysis concerns the impact of the technology on:

- Local and regional emissions of greenhouse gases

- Local landscape and nature conservation

- $\quad$ Risk abatement

As with the social indicators, some of these can be quantified in terms of emissions. However many of them are particular to an individuals or communities perception and are difficult to quantify.

\subsubsection{Emissions}

Emissions from Renewable Energy technologies are negligible during the actual generation stage. However emissions do occur during other stages of their Life Cycle (such as during the 


\section{Macrothink

manufacturing, transporting and constructing of the plant). The emissions looked at include emission of $\mathrm{SO} 2, \mathrm{NO} 2, \mathrm{CO} 2$ and other particulates.

\subsubsection{Visual Impact}

The visual impact of a renewable energy scheme is highly particular to perception. Two impacts are considered:

'Objective impact'- visual image of technology to observers in line of sight depends on land form and visibility and number of observers.

'Perceived impact'- depends on attitudes to existing land and scenery, and general attitudes technology.

\subsubsection{Noise}

Noise from the technology is mainly from the operation of the plant.

\subsubsection{Effect on Flora, Fauna}

The effect on wildlife, biodiversity, soil and local water sources on the whole process.

\subsubsection{Site Selection/Landscape}

Including

The planning process costs

Sitting- on land used for other purposes

Effect on land use

\subsubsection{Risk Abatement}

This refers to the risks that could be averted if a renewable energy technology substitutes for a conventional fuel, i.e. diesel spills.

In terms of Energy payback, the average wind farm pays back the energy used in its manufacture within three to five months, and over its lifetime a wind turbine will produce over 30 times more energy than was used in its manufacture.

In local terms the most important externality is the perceived noise and visual intrusion. As discussed in the background report and at the subsequent workshop these can be significantly reduced through good site planning, with criteria as to the acceptable range.

Other negative environmental impacts with wind turbines can be birds affected by injury/death through colliding with the turbine or disturbance to breeding/nesting. However these are generally low (less than those colliding with overhead transmission lines are).

Wind turbines can have dual land use- the capture of wind energy requires turbines to be spread over a large area. However the base of a wind turbine uses less than $0.2 \%$ of the land it occupies. The remaining land can be used for agriculture. 


\section{Macrothink}

\subsubsection{Social Impact Indicators}

There are potential good community benefits with wind turbines. These have already been discussed in the determination of the flagship projects, although these apply specifically to the lower bound option utilising appropriate implementation of small clusters of smaller wind generators:

- A financial return for the community, landowners and investors

- Diversification of rural incomes

- An increase in local employment as discussed below

- A contribution towards environmental sustainability and for combining with Green Tourism.

- Some degree of control over the scheme for the community.

- A sense of satisfaction for those involved and building capacity and strength of community

In terms of employment numerous studies find that wind power compares favorably in its job creating capacity with coal and nuclear generated electricity. For example, 1995 report on the status of employment in the UK wind industry concluded that the job creation for operation and maintenance - essentially local in nature - are significantly higher than for coal powered and combined gas cycle turbine power stations, even taking into account mining and extraction of the latter. Of 1300 jobs estimated for the UK in 1995, 8\% were in operation and maintenance and $14 \%$ in construction.

12 MW (lower bound figures) can install on the IoW could be expected to produce $150-200$ jobs, an estimated 12-16 in operation and maintenance and 21-28 in construction. Obviously not all of these would necessarily be on the IoW and not all would be from local people but it would certainly be of a net gain for the country since it would not be replacing any existing jobs.

The figures discussed above are only direct employment gain and do not include indirect and induced employment, there would be additional employment figures in these groups.

Accidents to the public are extremely unlikely. There is a minute risk of accidents if part or the entire turbine blade detaches from the turbine whilst operating, although the risk of such accidents is very small indeed. There is no known occurrence of injury to a member of the public due to the operation of wind turbines. The risk of occupational accidents is likely to be greatest during the manufacturing and construction phase.

Wind turbines can produce a "shadow flicker" effect as sunlight passes through the rotating blades, which can produce a visual impact and could (potentially) induce attacks in epilepsy sufferers. However, this is highly unlikely and in any case these effects are minimized by keeping rotation rates below 50 r.p.m. for three-bladed machines.

There is no evidence to suggest that wind farms detract tourists, indeed many wind farms 


\section{Macrothink}

have themselves become tourist attractions.

\subsubsection{Off-Shore Wind Energy}

\subsubsection{Economic Impact Assessment}

The table below summaries the economic analysis for a possible off-shore wind system.

The system modeled is to achieve an upper bound of $50 \mathrm{MW}$ with a total 25 of $2 \mathrm{MW}$ machines in one wind farm.

Table 7. Economic indicators for off-shore wind

\begin{tabular}{|l|l|}
\hline Technology & Off-shore wind energy \\
\hline Bound & Upper \\
\hline System description & 1 \\
\hline Machine size (MW) & 2.0 \\
\hline Total Capital Cost (\$, millions) & 49.7 \\
\hline Fuel costs/annum (\$ k) & 0 \\
\hline O\&M costs/annum $(\$ \mathrm{k})$ & 621 \\
\hline Annuitized capital cost/annum $(\$ \mathrm{k})$ & 5,062 \\
\hline Lifetime & 20 \\
\hline Total annual energy production $(\mathrm{GWh})$ & \\
\hline Electricity & 160.0 \\
\hline Simple energy cost (p/kWh) & \\
\hline Electricity only & 1.9 \\
\hline Energy cost (p/kWh) & \\
\hline Electricity only & 3.6 \\
\hline
\end{tabular}

Sources: European Commission, Energy for the future: Renewable Sources of Energy

\subsubsection{Environmental Impact Indicators}

Most of the same issues apply to off-shore wind turbines in terms of visual impact. Recreational activities could also be affected and navigational routes.

\subsubsection{Social Impacts Indicators}

There would be fewer community benefits from the installation of large-scale off-shore wind energy that for smaller land based systems. The development of the offshore wind industry is on now beginning with the development of this new branch of the technology there is the involvement of companies from the offshore energy field. It is estimated that a $75 \mathrm{MW}$ off-shore installation would create 245 jobs. Some jobs will certainly be created away from the main centers of industry. 


\section{Ml Macrothink}

\subsubsection{Solar Water Heating}

\subsubsection{Economic Impact Indicators}

System 1: To achieve the heat equivalent of $0.2 \mathrm{GWh}$ per year. The capital cost is based only on use for domestic water heating in typical retrofit. The cost would be decreased if it involved significant use of SWH for swimming pool heating and/or bulk purchase, i.e. by housing associations

System 2: To achieve the heat equivalent of $0.5 \mathrm{GWh}$ per year. Here it assumes some economies of scale for bulk purchase of domestic systems i.e. by housing associations/new build figures would also improve further if including significant use of SWH for swimming pool heating.

The table below summaries the economic analysis for two possible solar water heater Scenarios:

Table 8. Economic indicators for Solar Water Heaters

\begin{tabular}{|l|l|l|}
\hline Technology & \multicolumn{2}{|l|}{ Solar water heating } \\
\hline Bound & Lower & Uppear \\
\hline System description & 1 & 2 \\
\hline System size $(\mathrm{m} 2)$ & $3-4$ & $3-4$ \\
\hline Total capital cost (\$, millions) & 0.45 & 0.65 \\
\hline Fuel costs/annum (\$k) & 0 & 0 \\
\hline O\&M costs/annum & 1 & 2 \\
\hline Annutised capital cost/annum $(\$ \mathrm{k})$ & 46 & 66 \\
\hline Life time & 20 Years & \\
\hline Total annual energy production $(\mathrm{GWh})$ & \multicolumn{2}{|l|}{} \\
\hline Heat & 0.23 & 0.49 \\
\hline Simply energy cost (p/kWh) & \multicolumn{2}{|l}{} \\
\hline Heat only & 10.5 & 7.0 \\
\hline Energy cost (p/kWh) & & 13.9 \\
\hline Heat only & 20.9 & \\
\hline
\end{tabular}

Sources: European Commission, Energy for the future: Renewable Sources of Energy

\subsubsection{Environmental Impact Indicators}

The environmental effects are low for solar water heaters especially, in terms of visual impact or noise.

\subsubsection{Social Impacts Indicators}

The installation of a limited number of SWH systems (i.e. 150 as indicated in the lower bound) could contribute to the creation of one job on the IoW8, based on the increased penetration that this would represent and certainly installing a larger number of systems would require the availability of local plumbers, trained in such installations. 


\section{Macrothink}

\subsubsection{Solar PV}

\subsubsection{Economic Impact Indicators}

The table below summaries the economic analysis for two possible solar water heater scenarios:

System 1: To achieve lower bound based on small domestic installations 10 off $1.5 \mathrm{kWp}$.

System 2: To achieve Upper bound based on small domestic installations 40 off $1.5 \mathrm{kWp}$ plus one large commercial installation $50 \mathrm{kWp}$.

Table 9. Economic indicator for Solar PV

\begin{tabular}{|l|l|l|}
\hline Technology & Solar PV & \\
\hline Bound & Lower & Upper \\
\hline System description & 1 & 2 \\
\hline System size $(\mathrm{kWp})$ & 1.5 & $1.5-50$ \\
\hline Total Capital Cost $(\$$, millions $)$ & 0.12 & 0.65 \\
\hline Fuel cost/annum $(\$, \mathrm{k})$ & 0 & 0 \\
\hline O\&M costs/annum $(\$, \mathrm{k})$ & 1 & 3 \\
\hline Annutised & 11 & 61 \\
\hline Life time & 25 Years \\
\hline Total annual energy production $(\mathrm{GWh})$ & \multicolumn{2}{|}{} \\
\hline Electricity & 0.01 & 0.08 \\
\hline Simple energy cost $(\mathrm{p} / \mathrm{kWh})$ & \multicolumn{2}{|}{} \\
\hline Electricity only & 47.4 & 35.6 \\
\hline Energy cost $(\mathrm{p} / \mathrm{kWh})$ & \multicolumn{2}{|l}{} \\
\hline Electricity only & 104.7 & 78.5 \\
\hline
\end{tabular}

Sources: European Commission, Energy for the future: Renewable Sources of Energy

\subsubsection{Environmental Impact Indicators}

Environmental impacts are low although there can be a visual impact if the panels are not integrated into the design of the house.

\subsubsection{Social Impacts Indicators}

All PV schemes can pose a health hazard. Fires could release toxic materials (depending on the module and system construction) but conventional fire precautions and the low level of emissions caused by fire would make these risks low especially in comparison to the normal risks from fire in the building. Occupational safety is an important issue for PV system; direct current (DC) electricity is more dangerous than the equivalent alternating current (AC) output. This risk can be minimized by the use of good operating practices and equipment, i.e. plug-in connectors, appropriate warning labels.

\subsection{Summary/Discussion of Findings}

Table for lower bound shows the economic, social and environmental analysis for the 
potential different renewable energy options for meeting certain targets for electricity and total energy demand.

This table shows the possible lower bound where $10 \%$ of electricity demand comes from renewable and $2.6 \%$ of total energy demand is from renewable, by the year 2011 .

Assumptions have been made to prepare this table

1) The first on shore wind option refers to $600 \mathrm{~kW}$ machines in 4 small farms each with 5 machines.

2) The second on shore wind option refers to one larger wind farm incorporating eight $1.5 \mathrm{MW}$ machines.

3) The direct economic cost includes no profit margin or transmission costs included (direct production costs only)

4) Direct economic cost is based on discount rate of $8 \%$

5) The SWH is a domestic based cost based only on use for domestic water heating in typical retrofit

6) For the electricity direct economic cost the lower bound of production cost indicated for current supply mix upper bound approx. $2.5 \mathrm{p} / \mathrm{kWh}$

7) Comparison is made only to gas and electricity.

8) Gas and electricity prices based on rates for domestic and industrial supply weighted for IoW sector distribution.

Table 10. Summary of cost benefit analysis for lower bounds for renewable targets for low

\begin{tabular}{|c|c|c|c|c|c|c|c|c|c|c|c|c|}
\hline $\begin{array}{l}\text { Lower } \\
\text { Bound }\end{array}$ & & & & & & & $\begin{array}{l}\text { Environ } \\
\& \text { Socia }\end{array}$ & almental & $\begin{array}{l}\text { Total } \\
\text { (Avg.) }\end{array}$ & Cost & & \\
\hline $\begin{array}{c}\text { Use/ } \\
\text { Technology }\end{array}$ & $\begin{array}{c}\text { Energy (heat) } \\
\text { used/ practicable } \\
\text { output } \\
\text { (GWh/annum) }\end{array}$ & $\begin{array}{c}\text { Energy } \\
\text { (electricity) } \\
\text { used/practicable } \\
\text { output } \\
\text { (GWh/annum) }\end{array}$ & $\begin{array}{c}\text { Capital } \\
\text { Cost } \\
(\$ 000 \\
000)\end{array}$ & $\begin{array}{c}\text { Direct } \\
\text { economist } \\
\text { cost } \\
(\mathrm{p} / \mathrm{kWh})\end{array}$ & $\begin{array}{c}\text { Price to } \\
\text { consumer } \\
(\mathrm{p} / \mathrm{kWh})\end{array}$ & $\begin{array}{l}\text { Simple } \\
\text { ROR }\end{array}$ & $\begin{array}{c}\text { Lower } \\
\text { band } \\
(\mathrm{p} / \mathrm{kWh})\end{array}$ & $\begin{array}{c}\text { Upper } \\
\text { band } \\
(\mathrm{p} / \mathrm{kWh})\end{array}$ & $\begin{array}{c}\text { Production } \\
\text { cost } \\
(\mathrm{p} / \mathrm{kWh})\end{array}$ & $\begin{array}{c}\begin{array}{c}\text { Price to } \\
\text { consumer } \\
(\mathrm{p} / \mathrm{kWh})\end{array} \\
\end{array}$ & $\begin{array}{l}\text { Indicator } \\
\text { ROR } \\
\text { (Simple) }\end{array}$ & $\begin{array}{c}\text { ROR } \\
\text { increase }\end{array}$ \\
\hline Gas & & & $\mathrm{n} / \mathrm{a}$ & 0.7 & 1.1 & & 0.4 & 0.8 & 1.2 & 1.7 & & \\
\hline Electricity & & & $\mathrm{n} / \mathrm{a}$ & 2.0 & 5.0 & & 0.8 & 1.5 & 3.2 & 6.1 & & \\
\hline $\begin{array}{c}\text { Wind-on- } \\
\text { shore }\end{array}$ & & 30.0 & 10.0 & 3.6 & & $14.9 \%$ & 0.1 & 0.1 & 3.7 & & $18.4 \%$ & $24 \%$ \\
\hline $\begin{array}{c}\text { Wind-off- } \\
\text { shore }\end{array}$ & & 30.0 & 8.0 & 2.9 & & $18.6 \%$ & 0.1 & 0.1 & 3.0 & & $23.1 \%$ & $24 \%$ \\
\hline $\begin{array}{c}\text { Solar-water } \\
\text { heating }\end{array}$ & 0.2 & & 0.45 & 20.9 & & $0.6 \%$ & & & & & $0.9 \%$ & $54 \%$ \\
\hline Solar-PV & & 0.01 & 0.12 & 104.7 & & $0.5 \%$ & 0.2 & 0.6 & 105.1 & & $0.6 \%$ & $24 \%$ \\
\hline
\end{tabular}

Sources: European Commission, Energy for the future: Renewable Sources of Energy 


\section{Macrothink}

Table for upper bound also shows the economic, social and environmental analysis for the potential different renewable energy options for meeting certain targets for electricity and total energy demand.

This table shows the possible lower bound where $45 \%$ of electricity demand comes from renewable and $10 \%$ of total energy demand is from renewable, by the year 2011.

Assumptions have been made to prepare this table

1) The on shore wind option refers to six $1.5 \mathrm{MW}$ machines in 2 clusters

2) The off shore wind option incorporates 25 machines of $2 \mathrm{MW}$ machines. Note that Prices for off-shore installations are expected to fall as experience is gained of installations

3) The direct economic cost includes no profit margin or transmission costs included (direct production costs only).

4) Direct economic cost is based on discount rate of $8 \%$.

5) The SWH assumes some economies of scale for bulk purchase of domestic systems i.e. by housing associations/new build figures would also improve further if including significant use of SWH for swimming pool heating.

6) For the electricity direct economic cost the lower bound of production cost indicated for current supply mix from Scottish \& Southern- upper bound approx $2.5 \mathrm{p} / \mathrm{kWh}$

7) Comparison are made only to gas and electricity because these are the energies that would be substituted by renewable technologies

8) Gas and electricity prices based on rates for domestic and industrial supply weighted for IoW sector distribution.

Table 11. Summary of cost benefit analysis for upper bounds for renewable targets for low

\begin{tabular}{|c|c|c|c|c|c|c|c|c|c|c|c|c|}
\hline $\begin{array}{l}\text { Upper } \\
\text { Bound }\end{array}$ & & & & & & & $\begin{array}{l}\text { Envirc } \\
\& \text { Soc }\end{array}$ & $\begin{array}{l}\text { nmental } \\
\text { ial Cost }\end{array}$ & $\begin{array}{r}\text { Total } \\
(\mathrm{Al}\end{array}$ & $\begin{array}{l}\text { Cost } \\
\text { g.) }\end{array}$ & & \\
\hline $\begin{array}{c}\text { Use/ } \\
\text { Technology }\end{array}$ & $\begin{array}{c}\text { Energy (heat) used } \\
\text { practicable output } \\
(\mathrm{GWh} / \text { annum })\end{array}$ & $\begin{array}{c}\text { Energy } \\
\text { (electricity) used/ } \\
\text { practicable output } \\
(\mathrm{GWh} / \text { annum })\end{array}$ & $\begin{array}{c}\text { Capital } \\
\text { Cost } \\
(\$ \cdot 000 \\
000)\end{array}$ & $\begin{array}{c}\text { Direct } \\
\text { economist } \\
\text { cost } \\
(\mathrm{p} / \mathrm{kWh})\end{array}$ & $\begin{array}{l}\text { Price to } \\
\text { consumer } \\
\text { (p/kWh) }\end{array}$ & $\begin{array}{c}\text { Simple } \\
\text { ROR }\end{array}$ & $\begin{array}{l}\text { Lower } \\
\text { band } \\
(\mathrm{p} / \mathrm{kWh})\end{array}$ & $\begin{array}{c}\text { Upper } \\
\text { band } \\
(\mathrm{p} / \mathrm{kWh})\end{array}$ & $\begin{array}{c}\text { Production } \\
\text { cost } \\
(\mathrm{p} / \mathrm{kWh})\end{array}$ & $\begin{array}{c}\text { Price to } \\
\text { consumer } \\
(\mathrm{p} / \mathrm{kWh})\end{array}$ & $\begin{array}{c}\text { Indicator } \\
\text { ROR } \\
\text { (Simple) }\end{array}$ & $\begin{array}{c}\text { ROR } \\
\text { increase }\end{array}$ \\
\hline Gas & & & $\mathrm{n} / \mathrm{a}$ & 0.7 & 1.1 & & 0.4 & 0.8 & 1.3 & 1.7 & & \\
\hline Electricity & & & $\mathrm{n} / \mathrm{a}$ & 2.0 & 5.0 & & 0.8 & 1.5 & 3.2 & 6.1 & & \\
\hline $\begin{array}{c}\text { Wind-on- } \\
\text { shore }\end{array}$ & & 45.0 & 12.0 & 2.9 & & $18.6 \%$ & 0.1 & 0.1 & 3.0 & & $23.1 \%$ & $24 \%$ \\
\hline $\begin{array}{c}\text { Wind-off- } \\
\text { shore }\end{array}$ & & 160.0 & 49.7 & 3.6 & & $16.0 \%$ & 0.1 & 0.1 & 3.7 & & $19.8 \%$ & $24 \%$ \\
\hline $\begin{array}{c}\text { Solar-water } \\
\text { heating }\end{array}$ & 0.5 & & 0.65 & 13.9 & & $0.8 \%$ & & & & & $1.3 \%$ & $54 \%$ \\
\hline Solar-PV & & 0.08 & 0.65 & 78.5 & & $0.6 \%$ & 0.2 & 0.6 & 78.0 & & $0.8 \%$ & $24 \%$ \\
\hline
\end{tabular}

Sources: European Commission, Energy for the future: Renewable Sources of Energy 


\section{MIN Macrothink}

\section{Carbon Emission, Environmental Degradation and Rules \& Responsibility for Banks}

\subsection{Carbon Emission}

Although Bangladesh is not a big emitter and the country has no obligation to reduce greenhouse gas emissions given its LDC status, the government has identified mitigation and low carbon development as one of the priority areas in its Climate Change Strategy and Action Plan 2009. Since 1991, however, some increase in CO2 emission has been observed with per capita emission of 0.3 metric tons in 2007 and projections suggest a rise to 0.38 by 2015. However Bangladesh shares less than $0.1 \%$ of global emission of $\mathrm{CO} 2$ compared with $24 \%$ of the USA.

Table 12. Climate and atmosphere- Bangladesh and rest of the world

(In thousand metric tons of $\mathrm{CO} 2$ )

\begin{tabular}{|l|l|l|l|}
\hline Carbon Dioxide (CO2) emissions & Bangladesh & Asia (Excl. Middle East) & World \\
\hline Total Emission,1998 & 23,359 & $7,360,942$ & $24,215,376$ \\
\hline Percentage change since 1990 & $52 \%$ & $38 \%$ & $8 \%$ \\
\hline $\begin{array}{l}\text { Emission as a percentage of global } \\
\text { CO2 production }\end{array}$ & $0.1 \%$ & $30.4 \%$ & \\
\hline Emission in 1998 from: & & & \\
Solid fuels & 326 & $4,020,885$ & $8,654,368$ \\
Liquid fuels & 8,193 & $2,304,231$ & $10,160,272$ \\
Gaseous fuels & 14,392 & 580,898 & $4,470,080$ \\
Gas flaring & 0 & 22,391 & 172,208 \\
Cement manufacturing & 448 & 432,537 & 758,448 \\
\hline
\end{tabular}

Sources: http//www.earthtrends.wri.org

\section{CO2 emissions by sources, Bangladesh, 1998}

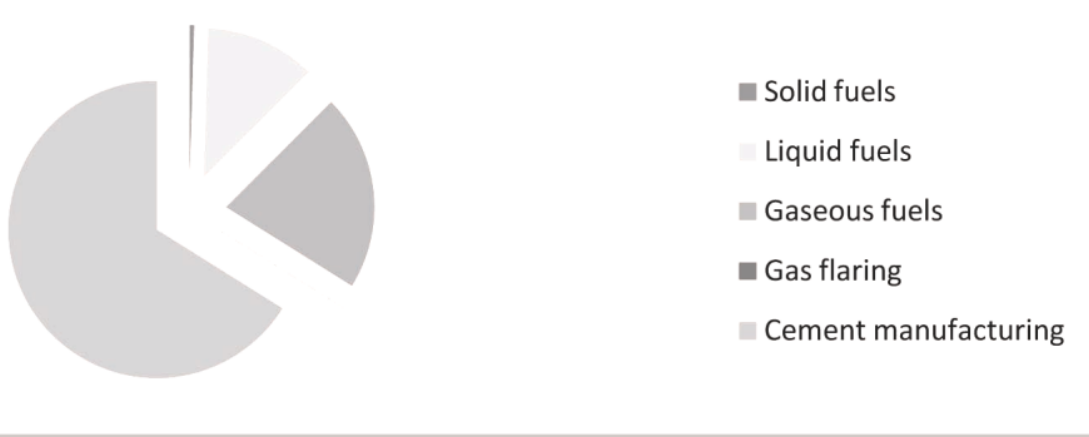

Figure 4. $\mathrm{CO} 2$ emission by sources 
Table 13. Per capita (CO2) emissions, 1998

\begin{tabular}{|l|c|c|c|}
\hline Per capita (CO2) emissions, 1998 & Bangladesh & Asia (Excl. Middle East) & World \\
\hline Thousand metric tons of CO2 & 0.2 & 2.1 & 4.2 \\
\hline Percent change since 1990 & $29 \%$ & $19 \%$ & $-2 \%$ \\
\hline $\begin{array}{l}\text { CO2emissions (in metric tons) per } \\
\text { million dollars GDP, 1998 }\end{array}$ & 535 & $\mathrm{X}$ & 773 \\
\hline Percent change since 1990 & $5 \%$ & $\mathrm{X}$ & $-10 \%$ \\
\hline $\begin{array}{l}\text { Cumulative CO2 emissions, } \\
1990-1999 \text { (in billion metric tons) }\end{array}$ & 408 & 161,972 & 933,686 \\
\hline
\end{tabular}

Sources: http//www.earthtrends.wri.org

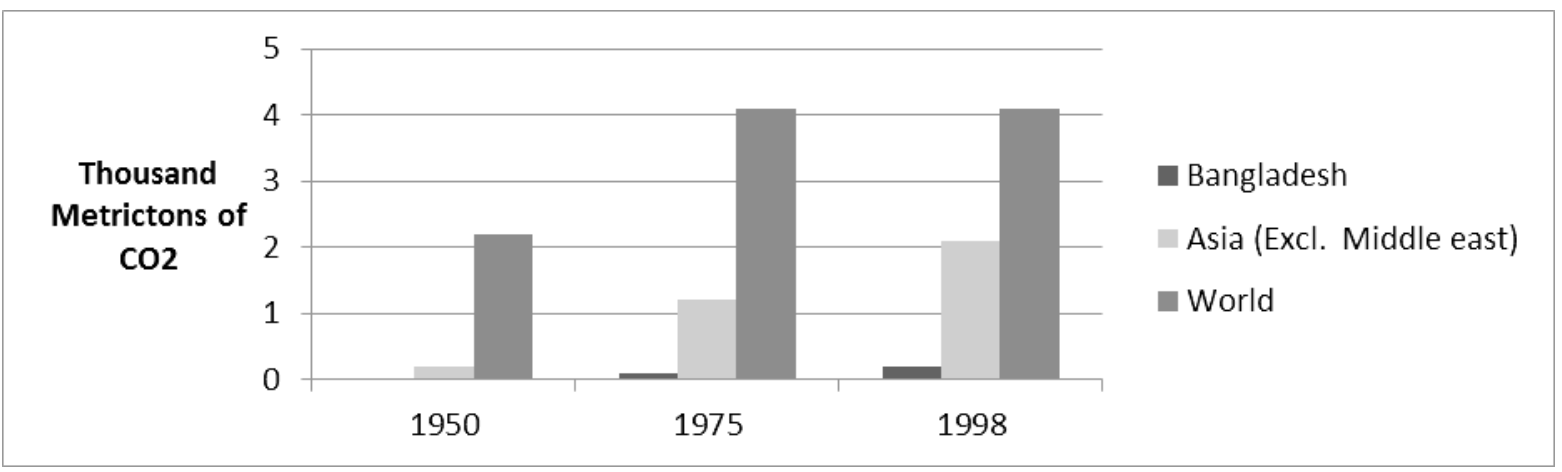

Figure 5. Per capita (CO2) emissions, 1998

Table 14. CO2 emissions by sector wise, 1990

(In million metric tons of $\mathrm{CO} 2$ )

\begin{tabular}{|l|l|l|l|}
\hline Carbon Dioxide (CO2) emissions & Bangladesh & Asia (Excl. Middle East) & World \\
\hline $\begin{array}{l}\text { Public electricity, heat production, and } \\
\text { autoproducers }\end{array}$ & 9 & 2,697 & 8,693 \\
\hline Other energy industries & 0 & 312 & 1,205 \\
\hline Manufacturing industries and construction & 8 & 1,915 & 4,337 \\
\hline Transportation & 3 & 943 & 5,505 \\
\hline Residential & 3 & 471 & 1,802 \\
\hline Other Sectors & 2 & 580 & 5,640 \\
\hline Total emissions all sectors & 26 & 6,918 & 27,180 \\
\hline
\end{tabular}

Sources: http//www.earthtrends.wri.org 


\section{CO2 emissions by sector, Bangladesh, 1999}

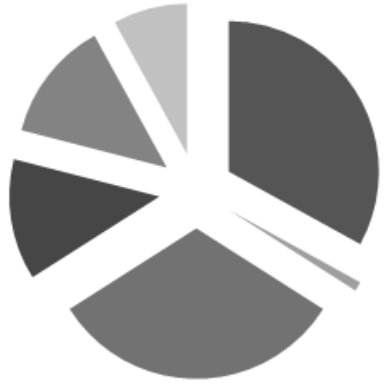

Electricity and heat production

- Other energy industries

Manufacturing and construction

- Transportation

Residences

Other sectors

Figure 6. CO2 emissions by sector, Bangladesh, 1999

Table 15. CO2 intensity, 1999

\begin{tabular}{|l|c|c|c|}
\hline CO2 Intensity, 1999 & Bangladesh & Asia (Excl. Middle East) & World \\
\hline $\begin{array}{l}\text { Emissions per total energy } \\
\text { consumption (metric tons CO2 per } \\
\text { terajoule energy) }\end{array}$ & 35 & 56 & 56 \\
\hline $\begin{array}{l}\text { Emissions per GDP (metric tons of } \\
\text { CO2/million \$ ppp) }\end{array}$ & 144 & 540 & 582 \\
\hline
\end{tabular}

Sources: http//www.earthtrends.wri.org

Table 16. Non-CO2 air pollution

(thousand metric tons)

\begin{tabular}{|l|l|l|l|}
\hline Non-CO2 Air pollution & Bangladesh & Asia (Excl. Middle East) & World \\
\hline Sulfur dioxide emissions, 1995 & 194 & 55,129 & 141,875 \\
\hline Nitrogen oxide emissions, 1995 & 358 & 28,962 & 99,271 \\
\hline Carbon monoxide emissions, 1995 & 7,514 & 258,325 & 852,415 \\
\hline Non-methane VOC emissions, 1995 & 1,043 & 42,036 & 159,634 \\
\hline
\end{tabular}

Sources: http//www.earthtrends.wri.org

\subsection{CO2 Market and the Current Status of International Climate}

The emission of greenhouse gases (GHGs) to the atmosphere is causing climatic disturbances of increasing severity, representing risks for the entire planet. Existing GHG emissions reduction policies mainly focus on setting up cap and trade systems (carbon markets) geared to achieving such reductions. The Kyoto Protocol, an international treaty established under the auspices of the United Nations, sets forth the guiding principles, objectives and legally binding targets imposed on the parties concerned until 2012. The purpose of the international 
negotiations underway is to set up a new regulatory framework for the post-2012 period.

\subsection{An Uptrend in the Atmospheric Concentrations of $\mathrm{CO} 2$}

Since the end of the 20th century, the average global temperature of the Earth has gone up by more than $0.7^{\circ} \mathrm{C}$. This increase has coincided with that of the carbon content in the atmosphere. Constant until the Industrial Revolution, the $\mathrm{CO} 2$ content has shown strong growth since 1750 as a result of the intensification of human activities that emit GHGs. In 2008, the atmospheric carbon content reached 385 ppm (parts per million), which is $38 \%$ higher than its preindustrial level (source: World Meteorological Organization, 2009).

\subsection{Environmental Degradation}

Degradation is progressing rapidly in many areas without any visible afforestation programs due to the lack of management programs for restoration of forests. Challenges to expand the tree cover include the absence of comprehensive mechanisms for the production and distribution of quality planting materials and efficient use of forest resources.

Although there are major opportunities for intervention to reduce greenhouse gas emissions in power generation, transportation, industrial production, agriculture, forestry and other sectors, there is a lack of facilitating technology, institutional support and dedicated financing. Some of the interventions that have been suggested are for example, diversification of crops and cropping patterns, afforestation and reforestation to capture the maximum benefit of $\mathrm{CO} 2$ sequestration. Removing these obstacles can have substantial impacts on the local economy through improved air quality, employment generation, poverty alleviation and gender equality. However, in the absence of comprehensive reviews that identify options to reduce emissions and quantify associated benefits, implementing appropriate policies is problematic.

\subsection{Responsibility of Bangladesh Banking Sector}

Although the GOB, UN bodies and other International organizations have been supporting initiatives towards environmental sustainability, it is clear that a major concentrated effort by government, donors and civil society organizations is essential. To support government, Bank could be the best helping hand. Because banks are the major and vast finance provider. So their responsibility is high to reduce carbon emission and environmental degradation.

1) Development of a long term environment, climate change and sustainable development vision focusing on government's goal and beyond.

2) Implementation of relevant national plans such as the Bangladesh Climate Change Strategy and Action Plan and National Capacity Development Action Plan.

3) Prevention of Degradation and to encourage rapid reforestation, expansion of social forestry programs.

4) Rapid implementation of sustainable energy programs and technologies that have local environment and development benefits.

5) Allocation of adequate resources and formation of strategic partnerships that include 


\section{Macrothink}

community level involvement for pollution abatement.

6) Monitoring and supervision of progress towards government based on credible environment and associated statistics.

\subsection{Regulation for GB in Bangladesh}

Key environmental legislation in Bangladesh include Water Pollution Control Ordinance, 1970; The environmental Pollution Control Ordinance 1977; The Bangladesh Environmental Conservation Act 1995; The Environmental Conservation Rules 1997; and The Environment Court Act, 2000. To protect the environment government also formulated Environment Policy in 1992 and made commitments as a signatory of a number of Multilateral Environmental Agreements. In December 1997, Bangladesh along with 160 other countries, completed negotiations of Kyoto Protocol.

To develop the policy for GB the following issue should be given emphasis:-

1) The main objective of the GB policy will save the environment and given priority to the society.

2) Ensure environmental sustainability through follow Millennium Development Goal (MDG), so that we can best use of our environment, natural resources etc. and contribute to prevent pollution.

3) Give priority who takes initiative to set up renewable energy like Solar energy, Biogas and Effluent treatment plant (ETP) for reducing electricity problem, natural gas reduction and environment pollution.

4) In case of growing industry loan, banks have to ensure that the industry has taken initiative to prevent environmental pollution.

5) In case of BMRE activities bank will take the same initiative followed by the industry.

6) Give priority and benefits to open L/C for importing ETP.

7) Due to change in environment agriculture is negatively impacted. So follow the credit principles of 2010-2011 for agricultural sector.

8) Ingraining CSR within the organization and client business.

9) Prefer online banking replacing traditional banking. Because online banking saves the use of papers. This is basically paperless banking. So it will improve number of trees in the country. Online banking will also reduce the cost of printing, post charge etc.

10) Environmental risk management of the credit should include in this policy.

11) In-house environment management of a bank should clearly specify in this policy.

12) Guidelines for banks to handle $\mathrm{CO} 2$ emitted companies' activities.

13) Guidelines to improve customers' conscious for green marketing. 


\section{Macrothink Institute ${ }^{\mathrm{TM}}$}

14) Bank companies must disclose their environmental information. And this report must send to the regulatory authority in Global Reporting Initiative (GRI) format.

15) There will be a guideline for an audit committee who will audit the green report of the banks.

\section{Conclusion}

\subsection{Implementation Problem of GB}

At the preliminary stage there might have some difficulties to implement GB. The type of difficulties like this:-

1) Bankers may not aware about this new banking system.

2) Ground reality is not always in line of reality. The green movement is gaining momentum in some corners of the financial industry and many banks include green and ethical commitments in their manifestos- but there are differences in their commitments and in many instances the ground reality is concerning.

3) Stakeholders, who are related with this green banking activities may not enough aware about GB. Their activities are inter-related. So they have to aware simultaneously.

4) Some issues are Complicated and yet to be Settled. For bank it is not easy to be green. It requires a thorough appraisal of all aspect of the business in order to truly green. Refusing to lend to dirty industries is one thing and making a commitment to clean up one's own act is even harder. Sometimes it is difficult for banks to balance environmental concerns and business demands.

5) Market based economic incentives for banks are an essential condition. Sufficient incentives is a crucial condition for the development of environment practices by corporate- both positive and negative. Policy and regulatory supports exist in most industrialized economics in favor of developing a congenial atmosphere for providing green products by banks.

6) Adequate consumer response may not happen. In a long run the trend towards green banking will be largely driven by the consumer behavior and consumption patterns. In this age of consumer sovereignty, it is very difficult to change our consumption habit, which is very much a part of our lives. In the market economy the more that is produced and the more that is purchased the more progress and prosperity. As consumption increases the resources have to be used to meet demands and as a result the scope of environmental degradation expands.

7) Policy makers responding to the changing banking environment may not accurate. Government and central bank are the proper authority to implement such policy.

\subsection{Recommendations}

Major stock holders need to play active roles for the development of GB practices in Bangladesh covering environmental management and governance, environmental risk 
management, in-house environmental performance, voluntary and leadership activities and environmental reporting.

The following recommendations are prescribing for the GB in Bangladesh:-

One, at first banks should introduce GB with the stakeholders, so that everybody could realize the importance of GB. Without introducing an unknown issue to the related party it will not a wise decision for banks to commence their activities.

Two, banks should formulated and adopt a good and broad Environmental or GB policy and Strategy approved by their Board of Directors. A High Powered committee comprises directors from the Board should be responsible for reviewing the bank's environmental policies, strategies and progress.

Three, improve online banking. This is important for bank to support their green banking strategy. Online statement and bill pay eliminates paper waste, saves gas and carbon emission and reduce printing costs and postage expense. Deforestation by encouraging paperless billing is great for the environment.

Four, transparency and Environmental reporting need more attention. This issue of environmental transparency and disclosure received must be improved in their reporting. They can disclose their report in chairman's message or Directors' report to the shareholders or they can present this report separately in their annual report.

Five, greening of the portfolio of the bank. When the bank will design their portfolio then it is very important for the bank to emphasis green sector. If possible neglect bad sector in all cases. Environment sensitive sectors in the country like agriculture, leather, fisheries, forestry, mining, gas, power generation, pharmaceuticals, constructions, textile etc. should be emphasized by the bank.

Six, a separate GB unit or cell should be established and assigned with the responsibility of designing, evaluating, and administering issues of the bank. A senior executive should be assigned with the responsibility of heading the unit. The unit will report to the high powered committee of the Board.

Seven, a 'green office guide' may be introduced for the employees for efficient use of water, electricity, gas, paper and reuse of equipment. Installation of energy efficient electronic equipment (at least in the newly constructed offices) and automatic shutdown of computers, fans, lights, AC etc. will help reducing electricity consumptions.

Eight, eco-finance should be preferred in financing activities. Consumer loan programs may be used for promoting environmental practices among clients. For example, through car loan program banks may promote purchase of fuel-efficient vehicles by the clients. Discount interest rates may be offered to the clients who use loans to buy vehicles with high mileage.

Nine, in case of opening L/C for green product (Solar energy technology, ETP, CNG-driven, Environment friendly technology etc.) commission/charge should be lower than other product, so that business holder or importer would motivate to use the green product. 


\section{Macrothink

Ten, an international community for green banking activities could be established. They will be the regulatory authority of the green banking activities. Like Basel committee (formulate capital adequacy for the bank) they will formulate the green activities of banks. High powered people will join this committee. The countries which are more affected by the environment should be higher posted in that committee.

\subsection{Conclusion}

In conclusion, it can be said we have to develop GB. Otherwise it will quite difficult for us to survive in this world. This is generally to protect our interest for ourselves. But it is not an easy task. Since it is a matter of huge finance, big investment, large capital it will quite difficult to commence GB in a developing country like Bangladesh. We have to face some difficulty in the preliminary stage. But after that it should bring some good for us. That means, though in the short run you may not find the fruitful result but in long run GB is the best solution for us.

\section{References}

Annual Report (2008). Brac Bank Limited.

Annual Report (2009). Dutch Bangla Bank Limited.

Annual Report (2009). Prime Bank Limited.

Atiur Rahman,(2014). Policy and Strategy of Green Banking in Bangladesh.

Bank of America. (2009). Sustainability report 2007/08, Bank of America, USA. Retrieved from http://www.timeinc.com/_assets/timeinc_susstainability.pdf

BIBM. Workshop papers on "Green Finance".

Chandrad, Prasanna. (2005). Projects-Planning Analysis, Selection, Financing, Implementation and Review (6th ed.). Tata McGraw-H.

European Commission (1996). Energy for the future: Renewable Sources of Energy. Green Paper for a community Strategy.

Habib, Ahsan. (2010). Seminar on "Green Banking Initiatives: Opportunities for Bangladesh".

http//www.earthtrends.wri.org

http//www.icicibank.com

Peoples Report on Bangladesh Environment. (2001). Part-1, Chapter-10 and 11.

Review of CSR Initiatives in Banks (2008 \& 2009), Published by Bangladesh Bank.

UNDP. (2009). Bangladesh Millennium Development, Progress Report 2009, Chapter-iii, goal 7, pp. 111-126. 


\section{Macrothink

\section{Copyright Disclaimer}

Copyright reserved by the author(s).

This article is an open-access article distributed under the terms and conditions of the Creative Commons Attribution license (http://creativecommons.org/licenses/by/3.0/). 